УДК 616.6-007.1-06:613.168:615.37

DOI: $10.24061 / 1727-0847.17 .4 .2018 .3$

\title{
O.M. Шарапова
}

ДЗ «Дніпропетровська медична академія МОЗ України»

\section{МОРФОФУНКЦІОНАЛЬНІ ПРОЦЕСИ В ЯЄЧКАХ ЩУРІВ ПІСЛЯ ДІЇ ЕХІНАЦЕЇ ПУРПУРОВӦ̈}

\begin{abstract}
Резюме. У роботі висвітлені питання перебігу сперматогенного процесу в яєчках щурів у нормі і після вживання тваринами імуномодулятора $-7 \%$ спиртової настоянки ехінацеї пурпурової. В експерименті залучено 6 контрольних і 24 дослідних тварин, яким внутрішньошлунково вводили 7\% спиртову настоянку ехінацеї пурпурової у дозі 0,0018 мл/г маси тварини. В яєчках контрольних і експериментальних щурів статеві клітини утворювалися шляхом проходження всіх етапів спермато- і сперміогенезу 3 хвилеподібним процесом в сім'яних канальцях. Доведено, що при вживанні настоянки імуномодулятора в яєчках щурів активізувався процес сперматогенезу, що підтверджувалося збільшенням середнього діаметра сім'яних канальців яєчок до 0,252 $\pm 0,036$ мкм.
\end{abstract}

Ключові слова: сперматогенез; сім'яний каналець; щур; ехінацея пурпурова.

Пошук препаратів, що покращують імунний стан організму, а також кровопостачання органів, залишається актуальною проблемою сучасної науки, зокрема урології. В арсеналі медиків існує цілий комплекс препаратів, що мають такі можливості. Це препарати на основі гарбузового насіння, на основі екстракту з листя хмелю звичайного, біологічноактивних речовин, вилучених із суцвіть вільхи, берези (препарат «Альтабор») [1, 2]. Найбільшу популярність серед інших препаратів отримав препарат на основі листя Гінкго білоба [3]. Усі ці препарати мають сперматогенну дію, тобто покращують кровопостачання чоловічих статевих органів, прискорюючи сперматогенез $[4 ; 5]$. У цьому дослідженні приділена увага вивченню дії імуномоделюючого препарату - 7\% спиртової настоянки ехінацеї пурпурової на сперматогенну функцію яєчок із можливістю запропонування профілактичного і лікувального ефекту даного препарату в хірургії i, зокрема в урології [6].

Мета дослідження: встановити морфологічну перебудову структури яєчок щурів, що вживали імуномодулятор - 7\% спиртову настоянку ехінацеї пурпурової.

Матеріал і методи. У дослідженні використано 40 щурів-самиів лінії Вістар масою 180-200 2, із них контрольна група становила 6 самиів. Тваринам експериментальної групи внутрішньоилунково вводили 7\% спиртову настоянку ехінаиеї пурпурової у дозі 0,0018 мл/2 маси тварини впродовж n'яти днів (із понеділка по n'ятницю). Вивід тварин з експерименту проводився шияхом дислокаиії шийних хребичв на 30-ту добу (24 тварини) після введення імуномодулятора, із тварин вилучали яєчка.

3 епоксидних блоків яєчок виготовляли напівтонкі зрізи товщиною 1 мкм. Під час виготовлення гістологічних препаратів для забарвлення зрізів яєчок використовували метиленовий синій $i$ тетраборнокислий натрій. На зрізи яєчок наносили однакову кіькість крапель 1\% водного розчину метиленового синього і $1 \%$ водного розчину бури. Декілька разів проводили скельия над полум'ям газового пальника, не допускаючи закипання рідини. Промивали під тонким струменем теплої водопровідної води, висушували, покривали бальзамом [6]. Проводили опис гістологічних препаратів під бінокулярним мікроскопом. Препарати фотографували за допомогою иифрової фотокамери та мікроскопу "LEICA CME" (об'єктив Plan $\left.4^{x} \infty /-, 10^{x} x / 0.25,40^{x} x / 0.65 \infty / 0.17\right)$. Мікроморфометричне дослідження об'єктів здійснювали на комплексі, до складуякого входили мікроскоп "LEICA CME”, иифровий фотоапарат Olympus (модель NO.E - 300DC 9V, № Я625517820) із n'ятимегапіксельною матрицею, що з'єднаний з мікроскопом системою адаптерів виробництва иієї ж фірми. Вимірювали довжину великого діаметра звивистих сім'яних канальиів яєчок із наступною статистичною обробкою одержаних результатів [7].

Результати дослідження та їх обговорення. В яєчках щурів контрольної групи відбувався активний процес сперматогенезу. Процес починався із сперматогоній утворенням таких клітин циклу 
- сперматоцитів I порядку або первинних сперматоцитів, що утворювалися шляхом мітозу. Далі утворювалися сперматоцити ІІ-го порядку або вторинні сперматоцити в результаті процесу мейоза. Наступна стадія сперматогенного циклу в яєчках щурів - у процесі мейоза поява сперматид І-го порядку. Останній етап циклу появи статевих клітин закінчувався формуванням зрілих сперматозоїдів внаслідок остаточних мейотичних явищ.

$\mathrm{У}$ різних ділянках сім'яних канальців яєчок процес формування статевих клітин проходив неоднаково і знаходився на різних стадіях. На поперечних зрізах канальців визначено, що в одних місцях процес закінчувався формуванням сперматоцитів I-го порядку, у інших - сперматоцитів II-го порядку, у деяких - процес завершувався утворенням повноцінних сперматозоїдів. Увесь сперматогенний цикл проходив хвильоподібно: у тих місцях, де були сперматогоніііі, через деякий час з'являлися сперматозоїди. У середньому сім'яний каналець дорослого щура містив 12 хвиль по 2,6 см кожна $з$ коливаннями від 0,7 до 6 см. 20\% хвиль не мали порушень, 17\% мали їх більше трьох. Якщо хвиля сперматогенного епітелію у щура була виявлена, то у людини ії встановити не вдалося.

Час, що проходив за період від стовбурової статевої клітини до зрілого сперматозоїда, називається часом сперматогенного циклу, і становив у щурів 46 днів. У людини період сперматогенного циклу нараховує 72 дні [8].

Гістологічне дослідження також показало, що сустентоцити або клітини Сертолі мали велике конусоподібне тіло 3 відростками, розташованими основою на базальній мембрані, а верхівка направлена до просвіту канальця. Відростки сустентоцитів анастомозували між собою та утворювали мікрооточення для клітин сперматогенного епітелію. У процесі утворення статевих клітин сустентоцити фагоцитували надлишки цитоплазми сформованих сперматозоїдів. Вивільнення сперматозоїдів із синцитію завершувалося переміщенням їх у просвіт сім'яного канальця (рис. 1 ; 2). Діаметр сім'яних канальців становив $0,226 \pm 0,030$ мкм $(\mathrm{p} \leq 0,05)$.

Внаслідок дослідження з'ясовано, що в яєчках тварин експериментальної групи на 30-ту добу експерименту сперматогенез у різних ділянках сім'яних канальців знаходився на різних етапах розвитку статевих клітин. Чітко контуровалися сперматоцити II-го порядку і сперматиди, в яких простежувалися фігури мейозу (рис. 3). Клітини Сертолі мали пікнотичний вигляд, знаходилися на базальній мембрані, вміщували 2 або 3 ядерця. Бі-

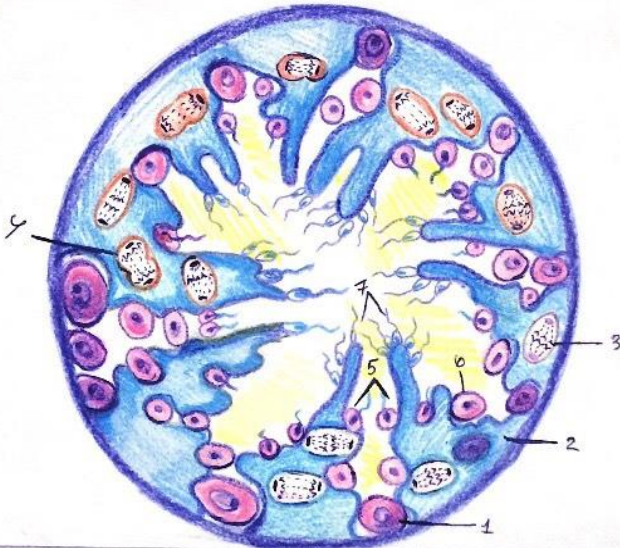

Рис. 1. Схема сперматогенезу в сім'яному канальиі яєчка шура у нормі. 1 - клітини Сертолі; 2 - сперматогонії; 3 - 1-й мейотичний поділ; 4 - 2-й мейотичний поділ; 5-сперматиди; 6-сперматоцити 1-го по-

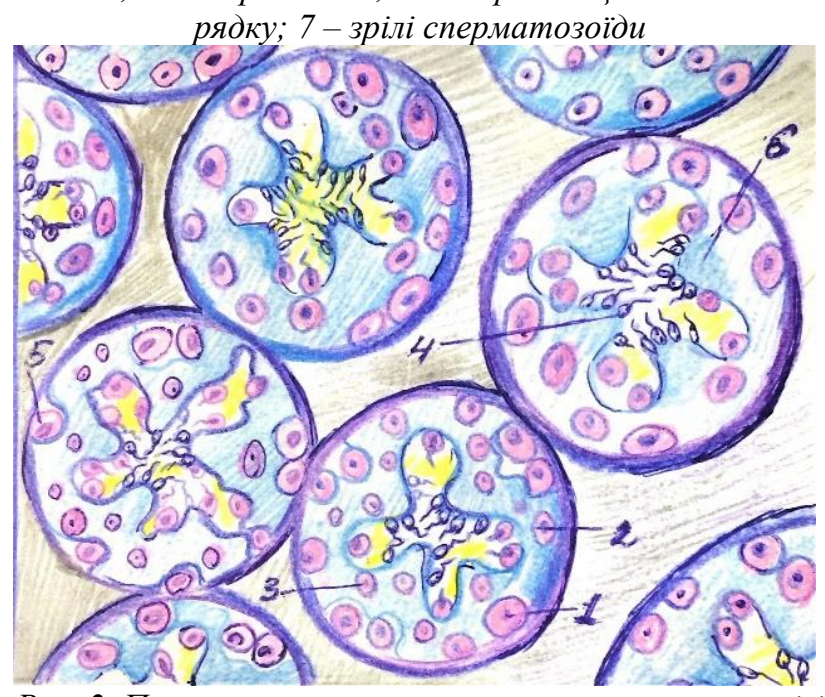

Рис. 2. Проиес сперматогенезу на поперечному розрізі яєчка шура у нормі. 1 - сперматогонії; 2 -

сперматоцити I-го порядку; 3 - сперматоцити II-го порядку; 4 - сперматозоїди; 5 - клітини Сертолі

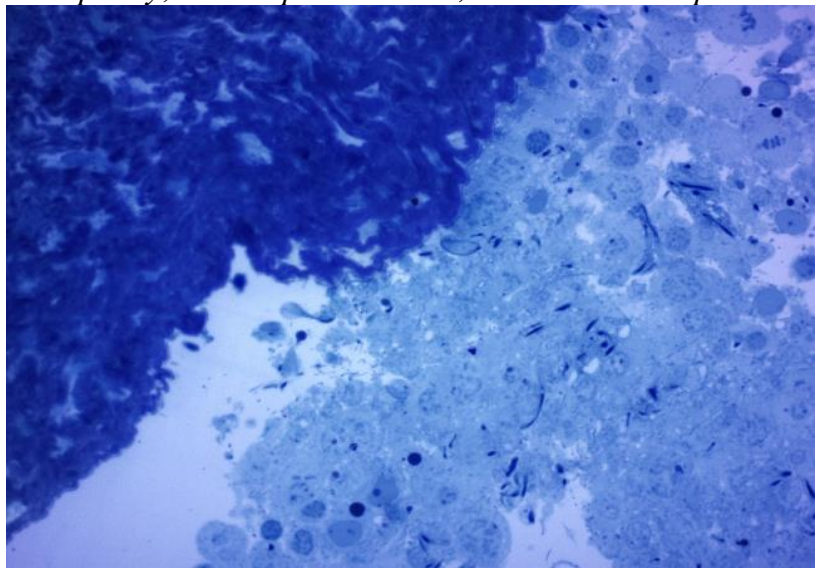

Рис. 3. Яєчко щура на 30-ту добу після введення настоянки ехінацеї пурпурової. Активний прощес сперматогенезу. Фарбування метиленовим синім. $x 400$ льшість сустентоцитів була конусоподібної форми, основою направленою до базальної мембрани, верхівкою - до просвіту канальця. Діаметр сім'яних ка- 
нальців яєчок досягав $0,252 \pm 0,036$ мкм ( $\leq \leq 0,05)$, що перевищувало показники контрольних тварин.

Висновок. Внаслідок проведених досліджень 3'ясовано, що процес сперматогенезу в яєчках щурів як контрольної, так і експериментальної груп відбувається хвилеподібно - із 12 хвилями довжиною 2,6 см у кожному сім'яному канальці. Діаметр сім'яних канальців яєчок тварин, що одер- жували 7\% спиртову настоянку ехінацеї пурпурової, у середньому збільшувався до $0,252 \pm 0,036$ мкм порівняно $з$ тваринами контрольної групи.

Перспективи подальших досліджень. Подальші дослідження будуть виконанні з метою встановлення морфологічної перебудови в яєчках під дією настоянки пурпурової на більш пізніх термінах експерименту.

\section{Список використаної літератури}

1. Крутских ТВ. Изучение фармакологических и технологических свойств субстанции Альтабора. Одесский медищинский журнал. 2015;4:11-3.

2. Грищенко ВИ, Рубан ОА. Дослідження порошків рослинних екстрактів з метою створення супозиторіїв для лікування захворювань передміхурової залози. Фармачевтичний часопис. 2013;4:92-5.

3. Пастухова ВА. Пошкодження сперматогенного епітелію яєчок, зумовленні дією хронічної гіпертермії. Морфологія; 2009; 3(40): 51-4.

4. Коваль ВМ, Грошовий ТА. Дослідження вибору рещипієнтів для одержання иинкових таблеток аспарагінату з аскорбіновой кислотою та екстрактом ехінацеї. Фармачевтичний часопис. 2013;1:74-8. 5. Музика НЯ, Костеньян МС, Паламар АО. Аналіз фармацевтичного ринку Украйни для лікування простатиту. Матеріали III науково-практичної конферениї: Фармакоекономіка в Україні. 2010; 2: 2445.

6. Багрій ММ, Діброва ВА, Попадинеиь ОГ, Грищук МІ. Методики морфологічних досліджень: монографія. Вінниия: Нова Книга; 2016. 328 c.

7. Елисеева ИИ, Юзбашев ММ. Общая теория статистики. Москва: Финансы и статистика; 2005. $324 c$.

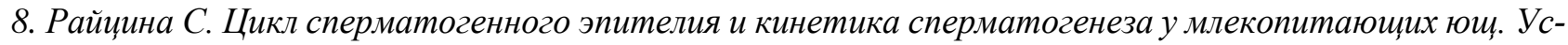
пехи современной биологии. 1967;63:135-53.

\section{References}

1. Krutskikh TV. Izucheniye farmakologicheskikh i tekhnologicheskikh svoystv substantsii Al'tabora [Study Of Pharmaco-Technological Properties Of Altabor Substance]. Odesskiy meditsinskiy zhurnal. 2015;4:11-3. (in Russian).

2. Hrytsenko VY, Ruban OA. Doslidzhennya poroshkiv roslynnykh ekstraktiv $z$ metoyu stvorennya supozytoriyiv dlya likuvannya zakhvoryuvan' peredmikhurovoyi zalozy [Research of plant extracts powders to create the suppositories for treating prostatopathies]. Pharmaceutical Review. 2013;4:92-5. (in Ukrainian).

3. Pastukhova VA. Poshkodzhennya spermatohennoho epiteliyu yayechok, zumovleni diyeyu khronichnoyi hipertermiyi [Injures of spermatogenesis epithelium of testis are caused by action of chronical hyperthermia]. 2009;3(4):51-4. (in Ukrainian).

4. Koval VM, Hroshovyy TA. Doslidzhennya z vyboru dopomizhnykh rechovyn z metoyu otrymannya tabletok tsynku asparahinatu z kyslotoyu askorbinovoyu ta ekstraktom ekhinatseyi [Study on the selection of substitutional products with the aim of reception of zinc tablets of acparaginate with ascorbic acid and echinacea extract]. Pharmaceutical Review. 2013;1:74-8. (in Ukrainian).

5. Musica AE, Kostyanian MS, Palamar AO. Analiz farmatsevtychnoho rynku Ukrayiny dlya likuvannya prostatytu [Analysis of the pharmaceutical market of Ukraine for the treatment of prostatitis]. Farmakoekonomika $v$ Ukrayini Proceedings of the 3rd Scientific and Practical Conference. 2010; p. 244-5. (in Ukrainian).

6. Bagriy MM, Dibrova VA, Popadinets OG, Grischuk MI. Metodyky morfolohichnykh doslidzhen' [Methodologies of morphological studies]. Vinnitsa: Nova Knyga; 2016. 328 p. (in Ukrainian).

7. Yeliseyeva II, Yuzbashev MM. Obshchaya teoriya statistiki [General theory of statistics]. Moscow:Finansy i statistika; 2005. 324 p.. (in Russian).

8. Raitsina SS. Tsikl spermatogennogo epiteliya i kinetika spermatogeneza u mlekopitayushchikh [The cycle of spermatogenic epithelium and the kinetics of spermatogenesis in mammals]. Uspekhi sovremennoy biologii.1967;63:135-53. (in Russian). 


\section{МОРФОФУНКЦІОНАЛЬНЫЕ ПРОЦЕССЫ В ЯИЧКАХ КРЫС ПОСЛЕ ДЕЙСТВИЯ ЭХИНА- ЦЕИ ПУРПУРНОЙ}

Резюме. В данной работе освещены вопросы протекания сперматогенного процесса в яичках крыс в норме и после употребления животными иммуномодулятора - 7\% спиртовой настойки эхинацеи пурпурной. В эксперименте было задействовано 6 контрольных и 24 опытных животных, которым внутрижелудочно вводили 7\% спиртовую настойку эхинацеи пурпурной в дозе 0,0018 мл/г массы животного. В яичках контрольных и экспериментальных крыс половые клетки образовывались путем прохождения всех этапов спермато- и спермиогенеза с волнообразным процессом в семенных канальцах. Доказано, что при использовании настойки иммуномодулятора в яичках крыс активизировался процесс сперматогенеза, что подтверждалось увеличением среднего диаметра семенных канальцев яичек до $0,252 \pm 0,036$ мкм.

Ключевые слова: сперматогенез; семенной каналец; крыса; эхинацея пурпурная.

\section{MORPHOFUNCTIONAL PROCESSES IN THE TESTICLES OF RATS AFTER ECHINACEA PUR- PUREA EFFECT}

Abstract. The study deals with the issues of the spermatogenetic process in the testicles of rats in the norm and after administration of an immune modulator, $7 \%$ alcohol tincture of Echinacea purpurea. 6 control and 24 experimental animals receiving intragastrically $7 \%$ alcohol tincture of Echinacea purpurea at the dose of $0.0018 \mathrm{~m} / \mathrm{g}$ of animal body weight were used in the experiment. In the testicles of the control and experimental animals germ cells were formed by passing through all the stages of spermato- and spermiogenesis with a wave-like process in the seminiferous tubules. The process of spermatogenesis in the testicles of rats was found to be activated after immune modulator administration, which was evidenced by an increase in the average diameter of the testicular tubules to $0.252 \pm 0.036 \mu \mathrm{m}$.

Key words: spermatogenesis, seminiferous tubule, rat, Echinacea purpurea.

\section{Відомості про автора:}

Шарапова Олена Миколаївна - кандидат медичних наук, викладач кафедри клінічної анатомії, анатомії і оперативної хірургії ДЗ «Дніпропетровська медична академія МО3 України».

Information about author:

Sharapova Elena M. - Candidate of Medical Sciences, lecturer of the Department of Clinical Anatomy, Anatomy and Operative Surgery, DZ «Dnipropetrovsk Medical Academy of Medical Sciences of Ukraine».

Надійшла 11.09.2018 p. Рецензент - проф. Хмара Т.В. (Чернівці) 